\title{
Association of immediate postpartum plasma calcium concentration with early-lactation clinical diseases, culling, reproduction, and milk production in Holstein cows
}

\author{
R. C. Neves, ${ }^{*}$ B. M. Leno,† M. D. Curler, $\ddagger$ M. J. Thomas, $\ddagger$ T. R. Overton,† and J. A. A. McArt ${ }^{* 1}$ \\ *Department of Population Medicine and Diagnostic Sciences, College of Veterinary Medicine, and \\ †Department of Animal Science, Cornell University, Ithaca, NY 14853 \\ fDairy Health and Management Services LLC, Lowville, NY 13367
}

\begin{abstract}
The objective of this study was to evaluate the association of postpartum plasma Ca concentration with early-lactation disease outcomes, culling within $60 \mathrm{~d}$ in milk, pregnancy to first service, and milk production. A total of 1,453 cows from 5 commercial dairy farms in New York State were enrolled in a prospective cohort study from February to November 2015. Blood samples were collected within $12 \mathrm{~h}$ of parturition, and plasma was submitted to a diagnostic laboratory for total Ca measurement. Early-lactation disease, reproductive performance, and milk production from Dairy Herd Improvement Association (DHIA) test-day data were compiled from each farm's management software. Multivariable Poisson regression models were built to evaluate the association of plasma $\mathrm{Ca}$ with the risks of retained placenta $(\mathrm{RP})$, metritis, displaced abomasum (DA), clinical mastitis, culling within $60 \mathrm{~d}$ in milk, and pregnancy to first service. Repeated-measures ANOVA were used to evaluate the association of Ca at parturition with milk production across the first 9 DHIA tests. Herd was considered a random effect in all models. Primiparous cows were modeled separately from multiparous cows if differential responses were observed. Calcium was not associated with the risk of RP, metritis, clinical mastitis, or pregnancy to first service in primiparous or multiparous cows. For multiparous cows only, higher Ca concentration tended to be associated with increased culling within the first $60 \mathrm{~d}$ in milk. Multiparous cows with $\mathrm{Ca} \leq 1.85 \mathrm{mmol} / \mathrm{L}$ had an increased risk of being diagnosed with a DA compared with cows with $\mathrm{Ca}>1.85 \mathrm{mmol} / \mathrm{L}$. For the milk production models, Ca was not associated with the amount of milk produced within the first 9 DHIA tests in primiparous cows; however, multiparous cows
\end{abstract}

Received June 9, 2017.

Accepted September 16, 2017.

${ }^{1}$ Corresponding author: jmcart@cornell.edu with $\mathrm{Ca} \leq 1.95 \mathrm{mmol} / \mathrm{L}$ produced, on average, $1.1 \mathrm{~kg}$ more milk per day across the 9 DHIA tests than their multiparous counterparts with $\mathrm{Ca}>1.95 \mathrm{mmol} / \mathrm{L}$. Our results indicate that plasma $\mathrm{Ca}$ concentration measured within $12 \mathrm{~h}$ of parturition is a poor predictor of earlylactation health outcomes. Reduced Ca concentration in the immediate postpartum period was associated with higher milk production in multiparous cows. From these results, we caution that studies attempting to categorize subclinical hypocalcemia based on a single sample in the immediate postpartum period could misclassify the disorder.

Key words: dairy cow, calcium, subclinical hypocalcemia, milk production

\section{INTRODUCTION}

Parturition marks a key period in the productive cycle of a dairy cow as it is characterized by sudden dietary and hormonal changes and social challenges. Consequently, early-lactation cows are at a high risk for developing metabolic diseases that can directly affect their lactation performance. Subclinical hypocalcemia (SCH; low blood Ca concentration without clinical signs of ataxia or paresis) is one of the metabolic disorders in early lactation that can detrimentally affect the productivity of the postparturient cow. Around 50\% of recently calved multiparous cows are believed to suffer from the condition (Reinhardt et al., 2011).

Traditionally, $\mathrm{SCH}$ has been classified as serum or plasma total $\mathrm{Ca}$ concentration $\leq 1.87 \mathrm{mmol} / \mathrm{L} \quad(7.5$ $\mathrm{mg} / \mathrm{dL}$; Goff et al., 1996), $\leq 1.95 \mathrm{mmol} / \mathrm{L}(7.8 \mathrm{mg} / \mathrm{dL}$; Massey et al., 1993), or $<2.0 \mathrm{mmol} / \mathrm{L}(8.0 \mathrm{mg} / \mathrm{dL}$; Oetzel et al., 1988; Oetzel, 1996). The number of studies in this area is continually growing, with the latest reports using higher classification cut-points (Chapinal et al., 2011, 2012; Martinez et al., 2012). However, some studies have found strong associations of lower Ca concentration in the postpartum period with detrimental health and production outcomes, whereas others have 
shown no associations. In a large study across herds in the United States and Canada, cows with Ca concentrations $\leq 2.1$ and $\leq 2.2 \mathrm{mmol} / \mathrm{L}$ (sampled within wk 1 of parturition) had decreased milk production and increased odds of displaced abomasum (DA), respectively (Chapinal et al., 2011, 2012). Martinez et al. (2012), using a categorization of $\mathrm{SCH}$ with $\mathrm{Ca} \leq 2.14 \mathrm{mmol} / \mathrm{L}$ based on the lowest serum Ca concentration collected within 0 to $3 \mathrm{DIM}$, demonstrated that $\mathrm{SCH}$ was associated with metritis. Chamberlin et al. (2013), using a cut-point for $\mathrm{SCH}$ based on ionized $\mathrm{Ca}<1.0 \mathrm{mmo} / \mathrm{L}$ (approximately equivalent to $2.0 \mathrm{mmol} / \mathrm{L}$ of total $\mathrm{Ca}$ ) on the day of calving, found no associations between the condition and early-lactation disease outcomes. Differences in $\mathrm{SCH}$ classification between studies using Ca concentrations in blood samples collected at different time points relative to parturition may affect our ability to establish associations between Ca concentration and early-lactation outcomes. The literature currently lacks standardization of SCH classification, and there is no consensus as to when and how dairy consultants should more objectively assess $\mathrm{SCH}$ at the herd and cow levels.

If $\mathrm{SCH}$ classification could be accurately performed shortly following parturition, mitigation strategies could be better implemented and measured in an attempt to lessen the effect of the disorder in early lactation. We hypothesized that reduced Ca concentration in the immediate postpartum period would be associated with detrimental health and production outcomes. The objectives of our study were to evaluate the association of Ca concentration in plasma in the immediate postpartum period in a large, multi-herd observational trial with (1) early-lactation health outcomes, (2) culling within 60 DIM, (3) pregnancy to first service, and (4) milk production.

\section{MATERIALS AND METHODS}

A prospective cohort study was performed as part of a larger randomized clinical trial evaluating the effects of an oral Ca bolus supplement given shortly after calving on health and production outcomes. This study was approved by the Cornell University Institutional Animal Care and Use Committee (protocol 2014-0171). Prospective data obtained from cows that calved from February 21 to November 30, 2015, from 5 commercial dairy farms in New York State were used. A sixth farm was included in the randomized clinical trial; however, that farm did not comply with disease definition protocols adopted before the initiation of the study and therefore was not included in this cohort. For the remaining farms, control cows (i.e., no Ca supplementation) with a blood sample taken within $12 \mathrm{~h}$ of parturition were eligible to be included in this study. Blood samples were collected by trained farm personnel via coccygeal venipuncture using a 20 -gauge needle attached to a polypropylene syringe, transferred immediately into a 4-mL lithium heparin tube (Greiner Bio-One, Monroe, $\mathrm{NC}$ ), and stored at $4^{\circ} \mathrm{C}$. Samples were shipped to a central processing location twice a week for centrifugation $\left(1,000 \times g\right.$ for $10 \mathrm{~min}$ at $\left.22^{\circ} \mathrm{C}\right)$, plasma harvesting, and storage $\left(-20^{\circ} \mathrm{C}\right)$ until further analysis. At the end of the trial, plasma samples were submitted to the University of Illinois Veterinary Diagnostic Laboratory (Urbana, IL) for total Ca analysis (intra- and interassay CV $<1.0 \%$ ) using a high-throughput chemistry analyzer (AU680, Beckman Coulter, Brea, CA), with reagents provided by the same manufacturer.

To detect a difference of at least $1.5 \mathrm{~kg}$ of milk per test-day with $95 \%$ confidence between the $\mathrm{SCH}$ and normocalcemic groups, and assuming a SD of $8.0 \mathrm{~kg}$ per test-day per group and a $40 \%$ prevalence of SCH, 1,000 cows were necessary to have a study with $80 \%$ power (OpenEpi version 3.01; OpenEpi, Atlanta, GA).

Total mixed ration samples were collected once weekly from the close-up dry cow group at each farm, composited at the end of the study, and submitted to a commercial laboratory for wet chemistry analysis (Cumberland Valley Analytical Services, Hagerstown, MD), with methods as described by McCarthy et al. (2015). Analyzed DCAD of the close-up diets for each farm are given in Table 1.

Farm personnel recorded disease event data in DairyComp 305 (Valley Agricultural Software, Tulare, CA) using standard disease definition protocols discussed before the start of the study for retained placenta (RP; failure to expel fetal membranes within $24 \mathrm{~h}$ of parturition), metritis (fetid reddish to brownish uterine discharge often accompanied by systemic signs of illness), DA, and clinical mastitis (presence of visibly abnormal milk). Health, production, and reproduction records were extracted from the herd management software into Microsoft Excel (Microsoft Corp., Redmond, WA) before statistical analyses.

\section{Statistical Analyses and Model-Building Strategies}

All statistical analyses were performed in SAS software (version 9.4, SAS Institute Inc., Cary, NC). Descriptive statistics were performed using the FREQ, MEANS, and UNIVARIATE procedures. Parity was categorized into a 4-level variable (first, second, third, and fourth or greater). Calving ease score was dichotomized to represent cows that required small to no assistance or suffered dystocia during calving. A 2-level 
variable was created to represent the effect of calving season $($ warm $=$ June to August; cool $=$ February to May and September to November). In addition, the effect of lag in time from blood collection relative to parturition was considered as a 3-level variable [within (hh:mm) 4:00 h; between 4:01 and 8:00 h; between 8:01 and 12:00 h after calving]. Potential collinearity among calving-related variables (stillbirth, twinning, and the dichotomized calving ease score), parity, and Ca concentration were tested using the Pearson correlation coefficient (CORR procedure), Cohen's kappa coefficient (FREQ procedure), and principal component regression (PLS and FACTOR procedures; Yu, 2011). The variables stillbirth and twinning were collapsed into a single input due to collinearity concerns based on principal component regression.

The associations of potential predictor variables with the outcomes of interest were first screened by performing univariable analysis using chi-squared statistics. Variables unconditionally associated with the outcomes at $P \leq 0.2$ were offered to the multivariable models. A manual backward stepwise selection procedure was used to build final models, with variables at $P \leq 0.05$ remaining as final effects. If any covariate caused more than a $20 \%$ change in one or more estimates, they were retained as confounders. Herd was treated as a random effect in all models, and the effects of parity (considered a confounder a priori) and Ca concentration at parturition (predictor of interest) were kept in all models regardless of $P$-value. Biologically plausible interactions among the retained model variables and pairwise interactions with Ca concentration were tested in the final models. If the effect of Ca concentration at parturition (in a continuous scale) was statistically significant at $P \leq 0.05$, a receiver operating characteristic (ROC) curve was used to identify the Ca cut-point that could better predict the outcome based on maximized sensitivity and specificity, and Ca concentration was dichotomized accordingly. All ROC curve analyses were built using the LOGISTIC and GPLOT procedures of SAS; the method evaluates the ability of the variable of interest to detect a true event (sensitivity) and a false event (1 - specificity), depending on specified cut-points (Hosmer et al., 2013). The associations of Ca concentration at parturition with all outcomes were first explored in stratified multivariable models by parity (i.e., separate models for primiparous and multiparous cows). However, stratified models are only presented if differential effects between parities were found. Assessments of final model fit were performed with goodness of fit statistics based on deviance and Pearson's statistics for the models with binary outcomes and residual plot evaluation for the milk production outcome.

\section{Association of Ca with Clinical Diseases, Culling, and Pregnancy to First Service}

Statistical models for disease outcomes (RP, metritis $\leq 14$ DIM, DA $\leq 60$ DIM, and clinical mastitis $\leq 60$ DIM), culling $\leq 60$ DIM, and pregnancy to first service were fitted using the GLIMMIX procedure with a maximum likelihood estimation based on adaptive Gaussian quadrature (Capanu et al., 2013), Poisson distribution, and $\log$ link function.

Potential covariates for RP and metritis included calving season, lag in time from parturition to blood collection, parity, calving ease, and the collapsed variable representing twinning and stillbirth. After Ca concentration at parturition was found not to be associated with RP or metritis, the variable representing uterine diseases (presence or absence of RP, metritis, or both) on DA was considered as a covariate for that outcome model. All cases of RP and metritis happened before the diagnosis of DA. As only 1 primiparous cow was diagnosed with DA, the effect of Ca was evaluated

Table 1. Descriptive statistics by farm and parity group for the cohort of cows under study

\begin{tabular}{|c|c|c|c|c|c|}
\hline \multirow[b]{2}{*}{ Farm } & \multicolumn{2}{|r|}{ Primiparous } & \multicolumn{2}{|r|}{ Multiparous } & \multirow[b]{2}{*}{$\begin{array}{l}\text { Prepartum DCAD }{ }^{1} \\
(\mathrm{mEq} / 100 \mathrm{~g} \text { of } \mathrm{DM})\end{array}$} \\
\hline & $\mathrm{n}$ & $\begin{array}{c}\text { Total Ca }(\mathrm{mmol} / \mathrm{L}) \\
\text { Mean }(\mathrm{SD})\end{array}$ & $\mathrm{n}$ & $\begin{array}{c}\text { Total Ca }(\mathrm{mmol} / \mathrm{L}) \\
\text { Mean }(\mathrm{SD})\end{array}$ & \\
\hline$\overline{\mathrm{A}}$ & 57 & $2.27(0.11)$ & 140 & $2.08(0.20)$ & -6.9 \\
\hline $\mathrm{B}$ & 61 & $2.22(0.16)$ & 156 & $2.00(0.25)$ & -2.8 \\
\hline $\mathrm{C}$ & 100 & $2.29(0.10)$ & 240 & $2.02(0.20)$ & -5.5 \\
\hline $\mathrm{D}$ & 71 & $2.24(0.12)$ & 187 & $1.93(0.24)$ & $7.3 ; 14.1^{2}$ \\
\hline $\mathrm{E}$ & 61 & $2.25(0.10)$ & 343 & $1.95(0.26)$ & -2.8 \\
\hline
\end{tabular}


only in multiparous cows. For the model evaluating clinical mastitis, the effect of parity, previous lactation 305-d mature-equivalent milk production, and number of days dry were considered potential covariates.

The model evaluating the risk of culling for primiparous cows considered, as potential predictors, the effect of calving season, lag in time from parturition to blood collection, uterine diseases, clinical mastitis, and age at first calving. In the multiparous model, parity, the effect of uterine diseases, clinical mastitis, previous lactation 305-d mature-equivalent milk production, and number of days dry were considered potential predictors. As the multiparous model exhibited a tendency $(0.05<P$ value $\leq 0.10$ ) of $\mathrm{Ca}$ concentration to be associated with the risk of culling, models were developed separately for primiparous and multiparous cows.

The model evaluating risk of pregnancy to first service included an offset term to adjust for the different voluntary waiting periods between farms. Potential predictors considered were the effect of calving season, lag in time from parturition to blood collection, uterine diseases, and a dichotomized variable that represented whether the first service was based on heat behavior or timed AI. Farms A, C, and E used a Presynch-Ovsynch program for management of first breedings, and farm $B$ used an Ovsynch program. Farm D participated in an embryo transfer program that required a subset of cows to be managed as potential embryo recipients; therefore, as different cows within the herd were being submitted to different reproductive programs, the entire farm was removed from the analysis of this outcome to avoid potential bias.

\section{Association of Ca with Milk Production}

Milk production across 9 DHIA tests was evaluated to better represent the lactation response of the cows under study. Repeated-measures modeling was conducted using the MIXED procedure while accounting for repeated measurements within a cow and the nested effect of cows within a farm. The first-order auto regressive covariance structure was used during the modelbuilding process. Different covariance structures were tested in the final model and Toeplitz was chosen as it yielded the smallest Akaike's information criterion. Primiparous and multiparous cows were modeled separately due to differential responses. Potential covariates assessed during univariable analysis included calving season, lag in time from parturition to blood collection, age at first calving (primiparous model only), uterine disease before the first DHIA test, and somatic cell linear score at each DHIA test. In addition, for the multiparous cow model only, the effect of parity, previous lactation 305-d mature-equivalent yield, and number of days dry were considered potential covariates. As Ca concentration at parturition was significantly associated with milk production for multiparous cows, ROC curves were built considering different Ca concentration cut-points ranging from $1.75 \mathrm{mmol} / \mathrm{L}(7.0 \mathrm{mg} /$ $\mathrm{dL})$ to $2.15 \mathrm{mmol} / \mathrm{L}(8.6 \mathrm{mg} / \mathrm{dL})$ in increments of 0.02 $\mathrm{mmol} / \mathrm{L}$. The dichotomized cut-point that maximized the area under the ROC curve was chosen as the best predictor that could most appropriately differentiate milk production responses. The Ca variable modeled in a continuous scale was substituted by the dichotomized Ca cut-point variable in the final model for ease of interpretation of the results.

\section{RESULTS}

In total, 1,453 cows were eligible for enrollment in the study. Cows with gestation length $<260 \mathrm{~d}(\mathrm{n}=37)$ were removed. Therefore, 1,416 cows (350 primiparous and 1,066 multiparous) remained for the final analyses. The mean time from parturition to blood sampling was $3 \mathrm{~h}$. Descriptive statistics for the herds and the cows enrolled in the cohort, early-lactation disease frequency and culling, and pregnancy to first service are presented in Tables 1 and 2, respectively.

\section{Association of Ca with Clinical Diseases, Culling, and Pregnancy to First Service}

For the RP and metritis models, the association of parity $(P=0.1$ and $P=0.001$, respectively), calving difficulty $(P=0.002$ in both models $)$, the collapsed variable representing twinning and stillbirths $(P<0.001$ in both models), and the forced Ca concentration variable at parturition remained in the final model. Calcium concentration at parturition was not associated with the risk of $\mathrm{RP}(P=0.50)$ or metritis $(P=0.20)$.

The association of plasma $\mathrm{Ca}$ concentration at parturition with the risk of DA (multiparous cows only) remained in the final model $(P=0.006)$, along with the association of uterine diseases $(P=0.007)$ and the forced parity variable $(P=0.33)$. A ROC analysis using a Ca concentration cut-point of $\leq 1.85 \mathrm{mmol} / \mathrm{L}(7.4$ $\mathrm{mg} / \mathrm{dL})$ maximized the sensitivity $(54 \%)$ and specificity $(76 \%)$ of diagnosis of a DA (Table 3). The proportion of multiparous cows with Ca concentration $\leq 1.85$ $\mathrm{mmol} / \mathrm{L}$ in our data set was $25 \%(265 / 1,066)$.

For the model evaluating clinical mastitis risk within 60 DIM, only parity $(P=0.015)$ remained in the final model along with the Ca concentration variable $(P=$ $0.67)$. Cows in their third and fourth or greater lactation had increased risks of being diagnosed with clinical mastitis compared with cows in second lactation $(P=$ 0.02 and $P=0.04$, respectively) or primiparous cows 
Table 2. Proportion of early-lactation diseases, culling, and pregnancy to first service in the cohort of primiparous and multiparous cows under study from 5 farms in New York State

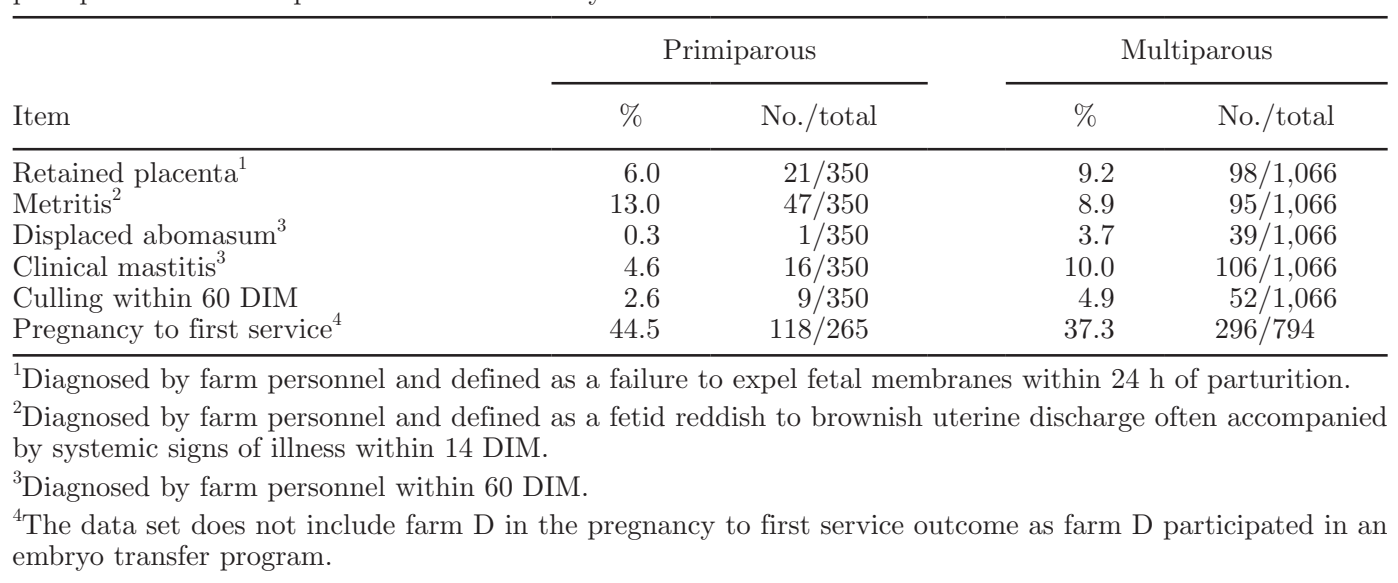

( $P=0.005$ and $P=0.01$, respectively). The risk of clinical mastitis did not differ between primiparous and second-lactation cows $(P=0.37)$.

For the model evaluating the risk of culling in primiparous cows, only the association of clinical mastitis $(P=0.001)$ and the forced $C a$ variable at parturition $(P=0.36)$ remained in the final model. In the multiparous model, Ca at parturition had a tendency to be associated with the outcome $(P=0.06)$ along with the association of clinical mastitis $(P<0.001)$ and parity $(P=0.002)$. An attempt to perform a ROC analysis on the association of Ca at parturition with the risk of culling determined that the variable was nondiscriminant of the outcome (area under the curve $=0.5$ ), which did not substantiate the dichotomization of the variable for further exploration. The direction of the association showed that increased $\mathrm{Ca}$ concentration at parturition tended toward greater culling risk (Table 4).

Calcium was not associated with the risk of pregnancy to first service $(P=0.88)$, and primiparous and multiparous cows were modeled together. The forced parity variable $(P=0.45)$ and the presence of uterine diseases $(P=0.04)$ were the other covariates that remained in the final model.

\section{Association of Ca with Milk Production}

Stratified models by parity demonstrated that $\mathrm{Ca}$ concentration at parturition was not associated with milk production in primiparous cows $(P=0.58)$. For primiparous cows, other variables that remained in the final model were somatic cell linear score at DHIA test $(P<0.001)$, occurrence of uterine diseases $(P=0.01)$, and DHIA test number. For multiparous cows, the Ca concentration variable in a continuous scale $(P \leq 0.001)$ was associated with increased milk production and dichotomized based on the ROC analyses. Calcium concentration $\leq 1.95 \mathrm{mmol} / \mathrm{L}(7.8 \mathrm{mg} / \mathrm{dL})$ was associated with overall higher milk production (area under the curve $=0.61$. Multiparous cows with $\mathrm{Ca} \leq 1.95 \mathrm{mmol} / \mathrm{L}$ produced on average, $1.1 \mathrm{~kg}$ more milk per day (1.9 $\mathrm{kg}$ if previous lactation 305-d mature-equivalent is not taken into account) across the 9 DHIA tests compared with cows with Ca concentration $>1.95 \mathrm{mmol} / \mathrm{L}$. When DHIA FCM yield was modeled instead of test-day milk yield, the estimate was $2.7 \mathrm{~kg}$ for the aforementioned comparison. The proportion of multiparous cows with Ca concentration $\leq 1.95 \mathrm{mmol} / \mathrm{L}$ in this data set was $39 \%(417 / 1,066)$. Additional variables accounted for in

Table 3. Final Poisson regression model evaluating the association of Ca concentration at parturition with the risk of displaced abomasum diagnosed within 60 DIM in 1,066 multiparous Holstein cows from 5 farms in New York State

\begin{tabular}{lccccc}
\hline Parameter & Estimate & $\mathrm{SE}$ & $P$-value & $\mathrm{RR}^{1}$ & $95 \%$ CI \\
\hline Parity group & - & - & 0.33 & - & - \\
$\quad$ Uterine disease & Referent & - & - & - & - \\
$\quad$ Healthy & 0.93 & 0.34 & 0.007 & 2.53 & $1.29-4.97$ \\
$\quad$ Retained placenta, metritis, or both & Referent & - & - & - & - \\
Ca concentration within 12 h of parturition & 1.03 & 0.37 & 0.006 & 2.81 & $1.35-5.85$ \\
$\quad 1.85 \mathrm{mmol} / \mathrm{L}$ & & & &
\end{tabular}

${ }^{1}$ Relative risk. 
Table 4. Final Poisson regression model evaluating the association of Ca concentration at parturition with the risk of culling for the first 60 DIM in 1,066 multiparous Holstein cows from 5 farms in New York State

\begin{tabular}{lccccc}
\hline Parameter & Estimate & $\mathrm{SE}$ & $P$-value & $\mathrm{RR}^{1}$ & $95 \%$ CI \\
\hline Clinical mastitis & Referent & - & - & - & - \\
No & 1.28 & 0.30 & $<0.001$ & 3.60 & $1.98-6.48$ \\
Yes & & & & & \\
Parity group & Referent & - & - & - & - \\
2 & 0.98 & 0.42 & 0.02 & 2.68 & $1.17-6.05$ \\
3 & 1.47 & 0.42 & $<0.001$ & 4.35 & $1.91-9.93$ \\
$\geq 4$ & 1.22 & 0.65 & 0.06 & 3.39 & $0.95-12.00$ \\
Ca concentration at parturition & & & &
\end{tabular}

${ }^{1}$ Relative risk.

the model included the forced confounding effect of the lag-time variable from parturition to blood sampling $(P$ $=0.06)$, and the main effects and 2-way interactions of DHIA test number with parity $(P<0.001)$, previous lactation 305-d mature-equivalent yield $(P<0.001)$, uterine diseases $(P<0.001)$, and season $(P=0.04)$. Figure 1 illustrates the association of the dichotomized Ca concentration variable on milk production across the 9 DHIA tests.

\section{DISCUSSION}

We performed a cohort study to evaluate the association of plasma Ca concentration from cows sampled within $12 \mathrm{~h}$ of parturition with the most common

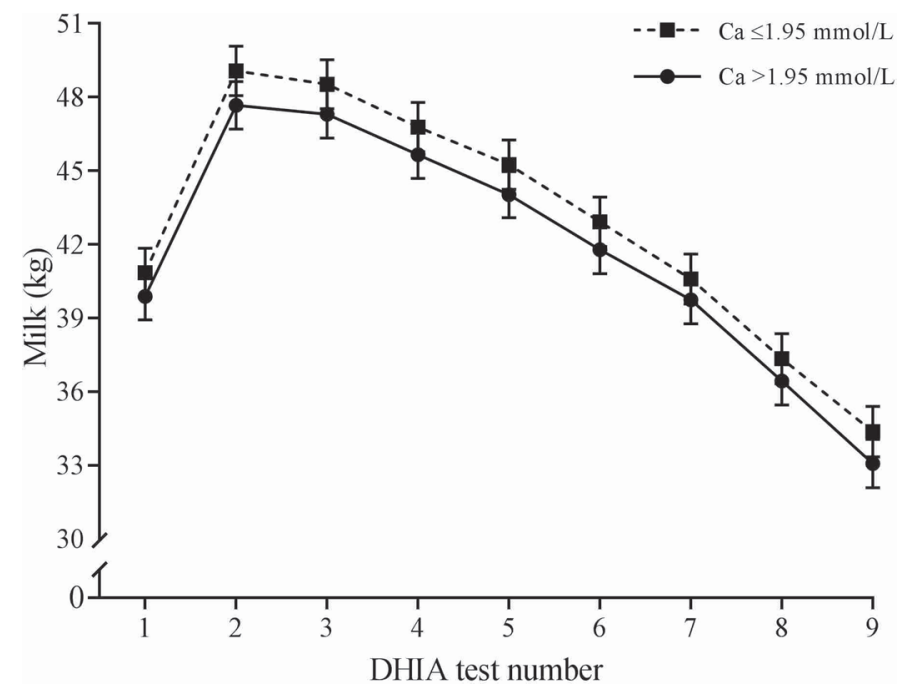

Figure 1. Milk production across 9 DHIA tests for 1,066 multiparous Holstein cows from 5 farms in New York State according to plasma Ca concentration measured within $12 \mathrm{~h}$ of parturition. Cows with Ca concentration $\leq 1.95 \mathrm{mmol} / \mathrm{L}(\mathrm{n}=417)$ produced, on average, $1.1 \mathrm{~kg}$ more milk per day compared with cows with Ca concentration $>1.95 \mathrm{mmol} / \mathrm{L}(\mathrm{n}=649)$. Error bars represent the SEM. Multiparous cows with plasma Ca concentration $\leq 1.95 \mathrm{mmol} / \mathrm{L}$ produced, on average (SEM), $42.9( \pm 0.9) \mathrm{kg}$ of milk per test-day compared with 41.8 $( \pm 0.9) \mathrm{kg}$ for cows with Ca concentration $>1.95 \mathrm{mmol} / \mathrm{L}$. early-lactation health disorders and production outcomes. Overall, plasma $\mathrm{Ca}$ concentration at calving was not associated with any of the outcomes analyzed for primiparous cows. Multiparous cows with reduced Ca concentration at calving were at increased risk of developing DA, although no associations with other early-lactation health outcomes were found. In addition, plasma Ca was associated with milk yield, such that multiparous cows with reduced Ca concentration were the highest milk producers. This work stresses the importance of better characterizing thresholds for $\mathrm{SCH}$ while taking into account the time of blood sampling relative to parturition in future studies.

Retained placenta and metritis are known to be associated with clinical hypocalcemia (Erb et al., 1985; Markusfeld, 1987; Correa et al., 1993).With the advancement of nutritional strategies capable of successfully preventing clinical hypocalcemia, much discussion and research has been focused on subclinical cases. We found no association of plasma Ca concentration measured shortly after calving with RP or metritis. One study limitation is that disease diagnosis was conducted by herd personnel, and it is plausible that these disorders were underdiagnosed, which could have affected our power to find associations. Moreover, the timing of blood sampling relative to parturition may have significantly influenced our ability to find associations. As $\mathrm{Ca}$ dynamics are variable within the first few days in milk, with the Ca nadir being reached around $24 \mathrm{~h}$ of parturition (Oetzel, 2013), blood sampling in the first few hours of the postpartum period can be less sensitive to detect associations. For instance, Chamberlin et al. (2013) found no associations of SCH with RP or metritis based on a serum sample collected within $24 \mathrm{~h}$ of parturition. Studies that used a sampling scheme based on measurements later than $24 \mathrm{~h}$ of calving have found associations of reduced $\mathrm{Ca}$ concentration with metritis, for example (Martinez et al., 2012; Rodríguez et al., 2017). As RP and metritis have been associated with an impaired immune response (Kimura et al., 2002; Jeon et al., 2016), maintenance of optimal Ca balance in the 
first few days following parturition can be paramount. Induction of SCH during a 24-h period in nonpregnant, nonlactating cows has been demonstrated to impair neutrophil function in vitro (Martinez et al., 2014). As a population of cows may have reduced serum Ca concentrations for a period exceeding $24 \mathrm{~h}$ in the early postpartum period (Caixeta et al., 2017), it is likely that the duration of the decreased Ca concentration is a more sensitive variable associated with those disorders. However, our main study objective was to evaluate the potential associations of plasma Ca concentration from a blood sample taken at a time convenient for most farm personnel, which occurred at the first handling of each cow after calving.

Calcium is known to be a key macromineral in smooth muscle contraction (Bremel, 1974). Lower Ca is thought to contribute to DA because the disorder has been associated with abomasal atony (Daniel, 1983; Geishauser et al., 1998). We found that cows with $\mathrm{Ca} \leq 1.85 \mathrm{mmol} / \mathrm{L}$ had a higher risk of developing DA. Massey et al. (1993) found that cows with Ca concentrations $<1.97 \mathrm{mmol} / \mathrm{L}$ and sampled within 12 $\mathrm{h}$ of parturition (an analogous scheme to our study) had increased odds of developing DA. LeBlanc et al. (2005) found that Ca was not a risk factor for DA, with fatty acids and BHB being better predictors of the condition in the pre- and postpartum periods. In a large multi-site study, Chapinal et al. (2011) found that prepartum serum $\mathrm{Ca}$, as well as BHB and fatty acids, were predictive of DA. As Ca and energy balance can be quite variable in the periparturient cow, potential associations between metabolites are also expected to change depending on the specific characteristics of each study data set (e.g., number of animals within parities sampled at a specific DIM, and extent of negative energy and $\mathrm{Ca}$ balance between parities).

Clinical hypocalcemia has been shown to be associated with clinical mastitis (Curtis et al., 1983, 1985), although we are unaware of any reports describing an association with SCH. It was hypothesized that lower Ca concentration at parturition, through its association with impaired immune function, could predispose cows to develop the disease in early lactation. However, Ca at parturition was not associated with the risk of clinical mastitis in our study.

No associations of Ca concentration on pregnancy to first insemination or time to pregnancy were found in studies that classified SCH in the first few hours following parturition (Chamberlin et al., 2013; Gild et al., 2015; Rodríguez et al., 2017; Wilhelm et al., 2017). Caixeta et al. (2017) demonstrated a negative effect of an extended duration of SCH (Ca concentration $<2.15$ $\mathrm{mmol} / \mathrm{L}$ throughout the first $3 \mathrm{DIM}$ ) on resumption of ovulation postpartum and pregnancy to first service.
However, their results did not demonstrate a detrimental association with pregnancy to first service if cows were categorized as SCH based on only 1 or 2 time points of Ca concentration $<2.15 \mathrm{mmol} / \mathrm{L}$ within the first 3 DIM. As with disease occurrences, it is plausible that an extended duration of reduced Ca concentrations in the early postpartum period is more predictive of poorer reproductive performance.

Plasma Ca concentration in the immediate postpartum period had a tendency to be associated with an increased culling risk in multiparous cows; interestingly, the model showed that greater Ca concentration tended toward greater culling risk. It is unlikely that culling risk was influenced by poor reproduction, as the time at risk evaluated was restricted to 60 DIM. As low milk production is one of the main factors of voluntary culling (USDA-NAHMS, 1996; Bascom and Young, 1998), it is possible that greater Ca concentration immediately postpartum was a marker of lower milk production, which consequently affected the risk of herd removal.

In response to decreased extracellular $\mathrm{Ca}$, parathyroid hormone (PTH) secretion plays a major role in Ca homeostasis (Jüppner and Potts, 2010). Parathyroidectomy during lactation has been shown to blunt the response of renal 1- $\alpha$-hydroxylase (a critical enzyme in Ca homeostasis) in hypocalcemic states (Lobaugh et al., 1993). The initiation of lactation heightens the demand for Ca and, physiologically, a decrease in plasma Ca following parturition is a likely component in the initiation of the orchestrated hormonal adaptations ensuing to support $\mathrm{Ca}$ balance and, indirectly, milk production. We found that lower $\mathrm{Ca}$ in the immediate postpartum period is associated with higher milk production in multiparous cows. In vitro studies done by VanHouten et al. (2004), using mammary epithelial cells, demonstrated that the Ca-sensing receptor is an active component of $\mathrm{Ca}$ balance as it can sense extracellular ionized $\mathrm{Ca}$ and participates in the transcellular $\mathrm{Ca}$ transport. More recently, decreased peripheral serotonin has been shown to negatively affect expression of the Ca-sensing receptor in mammary epithelial cells in lactating mice (Laporta et al., 2014). In addition, mammary serotonin regulates PTH-related protein gene expression (Hernandez et al., 2012); PTH-related protein is known to induce bone Ca mobilization during lactation (Thiede and Rodan, 1988; Thiede, 1994; Sowers et al., 1996). Cows with increased milk production might have a greater amount of Ca trafficking at the mammary gland level that would be transiently reflected in a more pronounced reduction of plasma $\mathrm{Ca}$ in the early postpartum period.

In an earlier study, we found that SCH classification at 0 or 2 DIM was associated with different risk factors (Neves et al., 2017). Therefore, longitudinal data sets 
evaluating $\mathrm{Ca}$ concentrations at different time points are necessary to establish when $\mathrm{SCH}$ classification should be performed to improve disease diagnosis and more accurately assess potential preventative measures.

\section{CONCLUSIONS}

Plasma Ca concentration in the immediate postpartum period was not associated with the risk of RP, metritis, or clinical mastitis diagnosis within the first 60 DIM. Multiparous cows with Ca $\leq 1.85 \mathrm{mmol} / \mathrm{L}$ had increased risk of DA and cows with $\mathrm{Ca} \leq 1.95 \mathrm{mmol} / \mathrm{L}$ produced more milk over 9 DHIA tests. In primiparous cows, Ca was not associated with any of the health and production outcomes evaluated. Future studies should be careful in classifying SCH based on a single time point for samples collected within $12 \mathrm{~h}$ of parturition, because the associations with early-lactation health and production performance do not indicate that low Ca during this timeframe is consistently negative (i.e., reduced plasma $\mathrm{Ca}$ was associated with an increased risk of DA but was also a positive characteristic for higher milk yield).

\section{ACKNOWLEDGMENTS}

This study was partly funded by New York Farm Viability Institute (Syracuse, NY), and Bio-Vet Inc. (Barneveld, WI). The authors thank the participating farms, Kathryn Bach (Cornell University, Ithaca, NY), and Lauren Pitman (Dairy Health and Management Services, Lowville, NY) for their great assistance during the study.

\section{REFERENCES}

Bascom, S. S., and A. J. Young. 1998. A summary of the reasons why farmers cull cows. J. Dairy Sci. 81:2299-2305.

Bremel, R. D. 1974. Myosin linked calcium regulation in vertebrate smooth muscle. Nature 252:405-407.

Caixeta, L. S., P. A. Ospina, M. B. Capel, and D. V. Nydam. 2017. Association between subclinical hypocalcemia in the first 3 days of lactation and reproductive performance of dairy cows. Theriogenology 94:1-7.

Capanu, M., M. Gönen, and C. B. Begg. 2013. An assessment of estimation methods for generalized linear mixed models with binary outcomes. Stat. Med. 32:4550-4566.

Chamberlin, W. G., J. R. Middleton, J. N. Spain, G. C. Johnson, M. R. Ellersieck, and P. Pithua. 2013. Subclinical hypocalcemia, plasma biochemical parameters, lipid metabolism, postpartum disease, and fertility in postparturient dairy cows. J. Dairy Sci. 96:7001-7013.

Chapinal, N., M. Carson, T. F. Duffield, M. Capel, S. Godden, M. Overton, J. E. Santos, and S. J. LeBlanc. 2011. The association of serum metabolites with clinical disease during the transition period. J. Dairy Sci. 94:4897-4903.

Chapinal, N., M. E. Carson, S. J. LeBlanc, K. E. Leslie, S. Godden, M. Capel, J. E. Santos, M. W. Overton, and T. F. Duffield. 2012.
The association of serum metabolites in the transition period with milk production and early-lactation reproductive performance. J. Dairy Sci. 95:1301-1309.

Correa, M. T., H. Erb, and J. Scarlett. 1993. Path analysis for seven postpartum disorders of Holstein cows. J. Dairy Sci. 76:1305-1312.

Curtis, C. R., H. N. Erb, C. J. Sniffen, R. D. Smith, and D. S. Kronfeld. 1985. Path analysis of dry period nutrition, postpartum metabolic and reproductive disorders, and mastitis in Holstein cows. J. Dairy Sci. 68:2347-2360.

Curtis, C. R., H. N. Erb, C. J. Sniffen, R. D. Smith, P. A. Powers, M. C. Smith, M. E. White, R. B. Hillman, and E. J. Pearson. 1983. Association of parturient hypocalcemia with eight periparturient disorders in Holstein cows. J. Am. Vet. Med. Assoc. 183:559-561.

Daniel, R. C. 1983. Motility of the rumen and abomasum during hypocalcaemia. Can. J. Comp. Med. 47:276-280.

Erb, H. N., R. D. Smith, P. A. Oltenacu, C. L. Guard, R. B. Hillman, P. A. Powers, M. C. Smith, and M. E. White. 1985. Path model of reproductive disorders and performance, milk fever, mastitis, milk yield, and culling in Holstein cows. J. Dairy Sci. 68:3337-3349.

Geishauser, T., D. Reiche, and M. Schemann. 1998. In vitro motility disorders associated with displaced abomasum in dairy cows. Neurogastroenterol. Motil. 10:395-401.

Gild, C., N. Alpert, and M. van Straten. 2015. The influence of subclinical hypocalcemia on production and reproduction parameters in Israeli dairy herds. Isr. J. Vet. Med. 70:16-21.

Goff, J. P., R. L. Horst, P. W. Jardon, C. Borelli, and J. Wedam. 1996. Field trials of an oral calcium propionate paste as an aid to prevent milk fever in periparturient dairy cows. J. Dairy Sci. 79:378-383.

Hernandez, L. L., K. A. Gregerson, and N. D. Horseman. 2012. Mammary gland serotonin regulates parathyroid hormone-related protein and other bone-related signals. Am. J. Physiol. Endocrinol. Metab. 302:E1009-1015.

Hosmer, D. W. J., S. Lemeshow, and R. X. Sturdivant. 2013. Applied Logistic regression. 3rd ed. Wiley, Hoboken, NJ.

Jeon, S. J., F. Cunha, X. Ma, N. Martinez, A. Vieira-Neto, R. Daetz, R. C. Bicalho, S. Lima, J. E. Santos, K. C. Jeong, and K. N. Galvao. 2016. Uterine microbiota and immune parameters associated with fever in dairy cows with metritis. PLoS One 11:e0165740.

Jüppner, H., and J. T. Potts. 2010. Roles of parathyroid hormone and parathyroid hormone-related peptide in calcium metabolism and bone biology: Biological actions and receptors. Comprehensive Physiology. John Wiley \& Sons Inc., New York, NY.

Kimura, K., J. P. Goff, M. E. Kehrli Jr., and T. A. Reinhardt. 2002. Decreased neutrophil function as a cause of retained placenta in dairy cattle. J. Dairy Sci. 85:544-550.

Laporta, J., K. P. Keil, C. M. Vezina, and L. L. Hernandez. 2014. Peripheral serotonin regulates maternal calcium trafficking in mammary epithelial cells during lactation in mice. PLoS One 9:e110190.

LeBlanc, S. J., K. E. Leslie, and T. F. Duffield. 2005. Metabolic predictors of displaced abomasum in dairy cattle. J. Dairy Sci. $88: 159-170$.

Lobaugh, B., S. C. Garner, J. A. Lovdal, A. Boass, and S. U. Toverud. 1993. Parathyroidectomy abolishes the increase of renal 25-hydroxyvitamin D-1 alpha-hydroxylase in lactating rats. Am. J. Physiol. 264:E981-985.

Markusfeld, O. 1987. Periparturient traits in seven high dairy herds. Incidence rates, association with parity, and interrelationships among traits. J. Dairy Sci. 70:158-166.

Martinez, N., C. A. Risco, F. S. Lima, R. S. Bisinotto, L. F. Greco, E. S. Ribeiro, F. Maunsell, K. Galvao, and J. E. Santos. 2012. Evaluation of peripartal calcium status, energetic profile, and neutrophil function in dairy cows at low or high risk of developing uterine disease. J. Dairy Sci. 95:7158-7172.

Martinez, N., L. D. Sinedino, R. S. Bisinotto, E. S. Ribeiro, G. C. Gomes, F. S. Lima, L. F. Greco, C. A. Risco, K. N. Galvao, D. Taylor-Rodriguez, J. P. Driver, W. W. Thatcher, and J. E. Santos, 2014. Effect of induced subclinical hypocalcemia on physiological responses and neutrophil function in dairy cows. J. Dairy Sci. $97: 874-887$. 
Massey, C. D., C. Wang, G. A. Donovan, and D. K. Beede. 1993. Hypocalcemia at parturition as a risk factor for left displacement of the abomasum in dairy cows. J. Am. Vet. Med. Assoc. 203:852-853.

McCarthy, M. M., T. Yasui, C. M. Ryan, G. D. Mechor, and T. R. Overton. 2015. Performance of early-lactation dairy cows as affected by dietary starch and monensin supplementation. J. Dairy Sci. 98:3335-3350.

Neves, R. C., B. M. Leno, T. Stokol, T. R. Overton, and J. A. A. McArt. 2017. Risk factors associated with postpartum subclinical hypocalcemia in dairy cows. J. Dairy Sci. 100:3796-3804.

Oetzel, G. R. 1996. Effect of calcium chloride gel treatment in dairy cows on incidence of periparturient diseases. J. Am. Vet. Med. Assoc. 209:958-961.

Oetzel, G. R. 2013. Oral calcium supplementation in peripartum dairy cows. Vet. Clin. North Am. Food Anim. Pract. 29:447-455.

Oetzel, G. R., J. D. Olson, C. R. Curtis, and M. J. Fettman. 1988. Ammonium chloride and ammonium sulfate for prevention of parturient paresis in dairy cows. J. Dairy Sci. 71:3302-3309.

Reinhardt, T. A., J. D. Lippolis, B. J. McCluskey, J. P. Goff, and R. L. Horst. 2011. Prevalence of subclinical hypocalcemia in dairy herds. Vet. J. 188:122-124

Rodríguez, E. M., A. Arís, and A. Bach. 2017. Associations between subclinical hypocalcemia and postparturient diseases in dairy cows. J. Dairy Sci. 100:7427-7434.

Sowers, M. F., B. W. Hollis, B. Shapiro, J. Randolph, C. A. Janney, D. Zhang, A. Schork, M. Crutchfield, F. Stanczyk, and M. Russell-
Aulet. 1996. Elevated parathyroid hormone-related peptide associated with lactation and bone density loss. JAMA 276:549-554.

Thiede, M. A. 1994. Parathyroid hormone-related protein: A regulated calcium-mobilizing product of the mammary gland. J. Dairy Sci. $77: 1952-1963$

Thiede, M. A., and G. A. Rodan. 1988. Expression of a calcium-mobilizing parathyroid hormone-like peptide in lactating mammary tissue. Science 242:278-280.

USDA-NAHMS. 1996. Dairy 1996, part I: Reference of 1996 dairy management practices. USDA-APHIS-VS, CEAH. Ft. Collins, CO. Accessed May 6, 2017. https://www.aphis.usda.gov/animal _health/nahms/dairy/downloads/dairy96/Dairy96_dr_PartI.pdf

VanHouten, J., P. Dann, G. McGeoch, E. M. Brown, K. Krapcho, M. Neville, and J. J. Wysolmerski. 2004. The calcium-sensing receptor regulates mammary gland parathyroid hormone-related protein production and calcium transport. J. Clin. Invest. 113:598-608.

Wilhelm, A. L., M. G. Maquivar, S. Bas, T. A. Brick, W. P. Weiss, H. Bothe, J. S. Velez, and G. M. Schuenemann. 2017. Effect of serum calcium status at calving on survival, health, and performance of postpartum Holstein cows and calves under certified organic management. J. Dairy Sci. 100:3059-3067.

Yu, C. H. 2011. Principal component regression as a countermeasure against collinearity. Pages 1-8 in Proc. Western Users of SAS Software Conf., San Francisco, CA. SAS Institute Inc., Cary, NC. 